SHS Web of Conferences 17, 01016 (2015)

DOI: $10.1051 /$ shsconf/20151701016

(C) Owned by the authors, published by EDP Sciences, 2015

\title{
Research on the Method to Assess the Development Quality of Regional Industry Based on CAF
}

\author{
Ping $\mathrm{Gu}^{\mathrm{a}}$, Yiwen Zhao \\ College of Economics and Management, Jiangsu University of Science and Technology, 212003 \\ Zhenjiang, Jiangsu, China
}

\begin{abstract}
With the development of new economy, the importance of development quality of regional industry is more and more visible. As a basic element of macro quality, the quality development of regional industry appears to be very crucial. Based on the Common Assessment Framework (CAF for short) generally used in Europe, this article constructs a flexible and general index system, and makes an exploratory attempt on the method to assess the development quality of regional industry.
\end{abstract}

Keywords. development quality of regional industry; Common Assessment Framework (CAF); assessment system

The first Chinese Quality Conference themed with "quality, innovation and development" was held in September 15, 2014, where the Prime Minister Keqiang Li pointed out that the quality is a centered reflection of comprehensive national strength and the key to create an updated version of Chinese economy. We should realize the "double improvement" of qualities for overall macro economy and micro product service. The realization of macroeconomic quality requires the local government to measure the development quality of regional industry more accurately in order to strengthen the government's macro control over the regional industry, improve the validity of government decision and facilitate the healthy development of local industry.

\section{Development quality of regional industry}

\subsection{Concept of development quality of regional industry}

With the economic development, the quality is becoming one of the important dimensions to measure the industrial development, and the consequent concept of "macro quality management" has made a considerable expansion from the traditional quality concept in the broadness of space and time. "Macro quality management" is to study the overall quality phenomenon in a country or region, and scientifically supervise the overall quality in an efficient way. ${ }^{[1]}$ The concept of "development quality of regional industry" is a subdivision based on the concept of "macro quality". Based on the previous research, this article defines the "development quality of regional

${ }^{a}$ Corresponding author: frank_ping@163.com 
industry" as the overall situation and future development potential of a certain industry in the aspect of economic and quality benefits in a particular region.

\subsection{Current situation of assessment about the development quality of regional industry}

Currently, the GDP is mostly taken as the measurement standard for the industries in the governmental jurisdiction. The quality benefits of a particular industry cannot be assessed by simply taking the economic value produced in an industry as a benchmark for the excellent development of an enterprise. The proposal of the concept "green GDP" has to some extent taken into account the impact of environmental pollution, deterioration of natural resources, low education degree, pollution out of control, improper management and other factors, but has not considered the synergistic effect of various resources and environments in the region, so it is unable to correctly or systematically assess the development quality trend of an industry in the region.

Most of the traditional means of quality description and quality assessment mode are for the quality of product or service, and hard to be directly used in the regional assessment of the macro industry. Hong Cheng ${ }^{[2]}$ (2009) proposed the regional Total Quality Index (TQI for short) measured for the quality development level within an established scope; Fornel proposed a region development quality index--American customer satisfaction index, ACSI for short), which created a new route for the region quality assessment. ${ }^{[3]}$ But the lack of systematic feature and pertinence to a certain industry, in some way, made those methods have some limitations in measuring the development quality of regional industry.

In the aspect of industrial assessment, Yicheng $\mathrm{Liu}^{[4]}$ (2009) proposed the concept of development quality of industry and constructed an index system for the high-end industrial development; Shuhua Hu, Zenghui, Li, Renyan Mou, et $\mathrm{al}^{[5]}$ (2012) proposed a "three-power" assessment model for the industry and said the strength and development level of the industry shall be assessed comprehensively in aspects, namely the international competitiveness, autonomic innovation power and benefits contribution power; Baofeng Shi and Guotai Chi ${ }^{[6]}(2014)$ quantitatively screened the indexes according to the principles of "maximum information content" and "redundant information deletion" and constructed an index system for the assessment of green industry. Lina $\mathrm{An}^{[7]}$ (2014) analyzed and constructed an index system for the cultural industry in three hierarchies, namely the industrial chain structure, measurement variation and index framework.

The above research has made a huge contribution to the industrial development study, and proposed some efficient measurement system for the industrial development quality, but there are still some defects in the assessment for the development quality of regional industry:

(1) The logic in each first-level index is not strong, unable to explain how the various indexes influence the result of industrial economy;

(2) It mostly proposed an assessment system with industrial features for a single industry rather than an index measurement system with universality.

(3) It mostly ignored the limitation of "region", as the differences in the different regions and industries require the index system to be constructed with certain flexibility.

(4) It focused more on the current situation of industrial economy and the future potential of economic development, but little on the impact the industrial development has on the society, environment and other aspects.

\section{Feasibility of CAF in the assessment of regional industry develop- ment}

Common Assessment Framework (CAF for short) is a tool for comprehensive quality management originating from the excellent mode in European Quality Foundation and the quality management 
mode in Public Administration University in German Speyer. The principle of CAF is to realize an excellent result of organizational performance, citizen/customer, human resources and society through leadership drive, strategy and planning, various partnerships and management of resources and process. This article expands the application field of CAF to the area of assessment for the industrial development quality to assess the development quality of regional industry together. It is relatively late for the domestic research and application of Common Assessment Framework. Xutao Liu and Xiangdong Zong ${ }^{[8]}$ (2005) discussed the use of Common Assessment Framework in China for the first time. Manchuan Wang ${ }^{[9]}$ (2005) made an analysis on the reference meaning of Common Assessment Framework in the performance assessment for the public departments in China in four perspectives, namely the performance assessment, application scope of performance assessment, selection of performance assessment standard and selection of assessment entity.

This article is devoted to find out the universal assessment system for the regional industry development by research. With the advantages of systematic measurement system and complete index framework, CAF becomes the basis on which the index system is constructed in this article.

\subsection{Objective applicability}

Compared to ISO9000 Management System and Assessment Standard for Excellent Performance, $\mathrm{CAF}$ is established to create a set of performance assessment system more suitable for public departments, which leads it to focus more on the social and ecological effects of measured entities in the process of measurement. It makes assessment in a way more suitable for the regional managers.

The common features of regional industry and public organization are as follows:

- democratic feedback system;

- operated in a framework with legislative power, law and supervision;

- related to politic level;

- allowing for the participation of stakeholders and balancing their demands;

- devoted to realize an excellent service delivery;

- measuring the value by money;

- purpose realization;

- management of modernization, innovation and reform.

A large number of common features of regional industry and public make it possible for CAF to assess the development quality of regional industry.

\subsection{Logical Completeness}

In the Common Assessment Framework in 2006, 9 major factors of CAF are described as "9-box model"[7] (as shown in Figure 1).

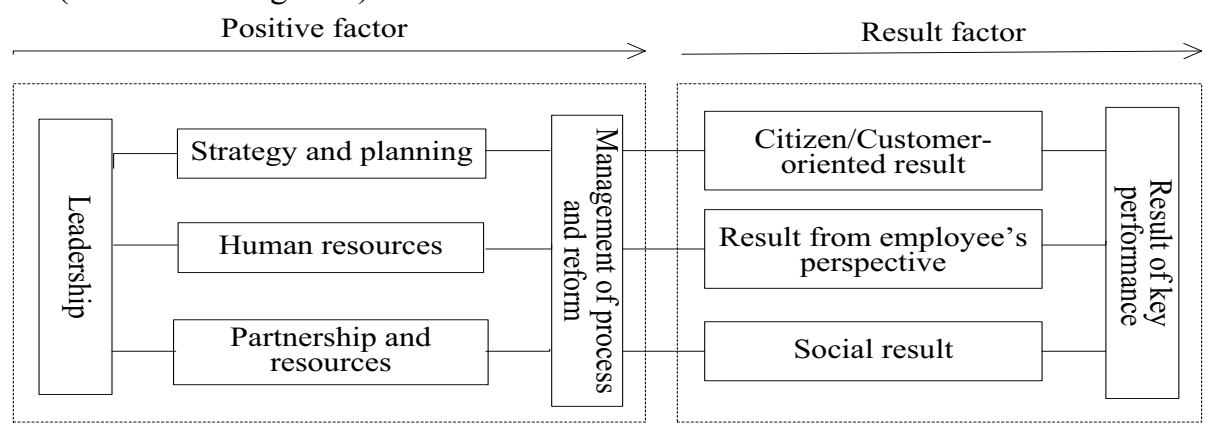

Innovation and study

Figure 1. CAF "9-box model". 
As shown in Figure 1, there's a strong logicality in the nine aspects of CAF, and the "positive factor" and "result factor" form a complete closed-loop management. The leadership" guides the overall situation and overall planning about "strategy and planning", "human resources", "partnership and resources", and it realizes the result from the "result" factor by "process and reform management", as well as achieves improvement by study and innovation of "result factor".

"PDCA" cycle is one of the most important tools for comprehensive quality management. As one of the tools for comprehensive quality management, CAF assessment system highlights the closed-loop management in system, which is one of its advantages in measuring the regional industry.

\subsection{Completeness of assessment index}

CAF can be summarized into the following three hierarchies: the highest hierarchy contains those 9 major factors; in the second hierarchy, there are 28 sub-standards that must be considered; the third hierarchy is the evidence required to be considered when grading the sub-standards. The grade will be given by the organization according to the intensity and validity of the evidence. CAF index system will not only consider the result factor, but also focus on the process inducing the result factor. The systematic index system takes all aspects about the measurement of industrial development quality into account.

\subsection{Compatibility of assessed content}

To prove the setting of CAF index complies with the measurement of development quality of regional industry, the organizational region manager, representatives in the industry and expert scholars have negotiated to form a demand list in the process of research (As shown in Table 1).

Table 1. Demand list for the assessment about the development quality of regional industry.

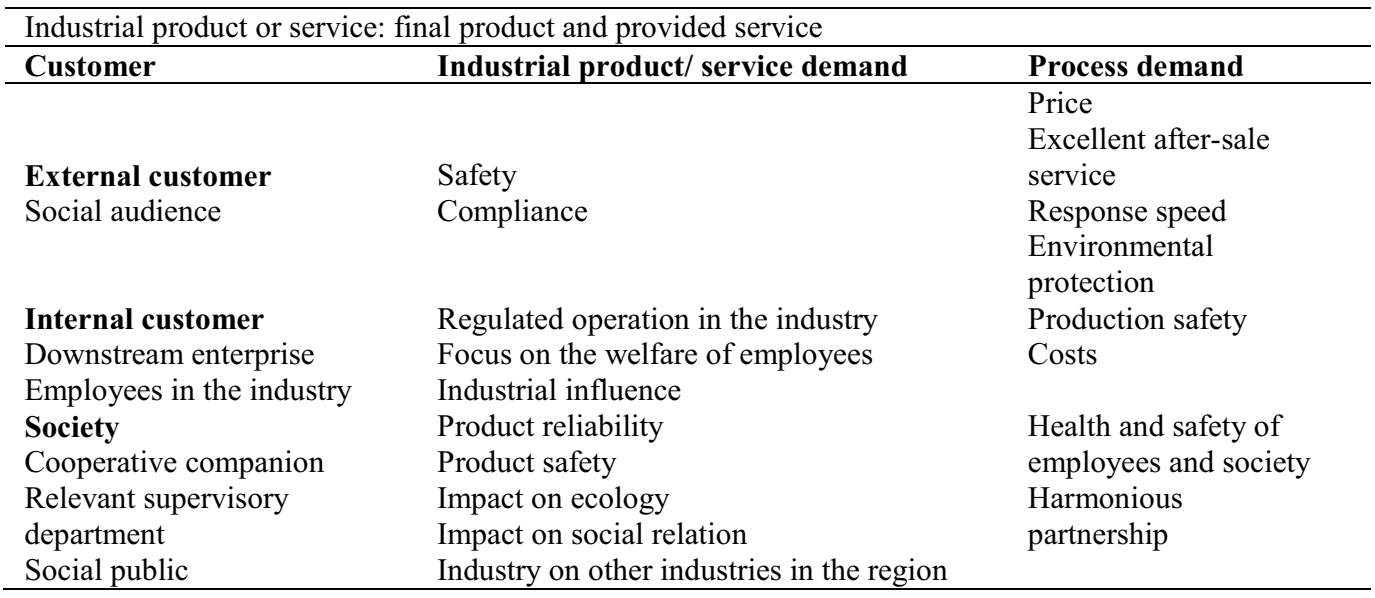

As the application quality house (As shown in Table 2) judges the applicability of measurement for the development quality of regional industry, it constructs the "left wall" of the house with customer demands, and the "roof" with CAF features. It also obtains the advantages of measurement for the development quality of regional industry from comparing CAF with other standards.

As shown in the "main body" section of the quality house, CAF can satisfy the demands of the internal customers, external customers and the social requirements on the assessment of regional industry. In the "right wall" section of the quality house, CAF is more applicable in design of the welfare of employees, social welfare, ecological problems and other aspects than other standards. 
Table 2. Quality house.

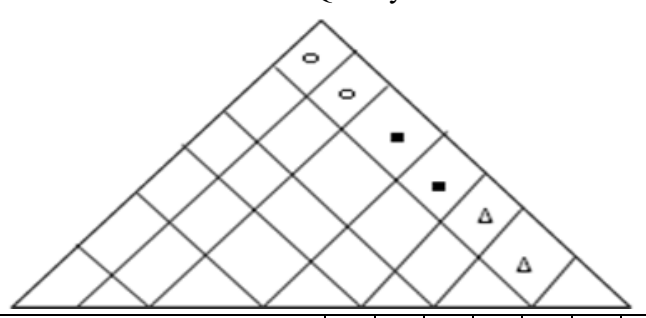

\begin{tabular}{|c|c|c|c|c|c|c|c|c|c|c|c|c|c|c|}
\hline \multirow{2}{*}{\multicolumn{2}{|c|}{$\begin{array}{l}\text { Relevance } \text { high } 5 \text { medium } 3 \Delta \text { low } 1 \\
\text { Other standards of } \bigcirc \mathrm{CAF} \square\end{array}$}} & $\mathbf{A}$ & B & $\mathbf{C}$ & D & $\mathbf{E}$ & $\mathbf{F}$ & $\mathbf{G}$ & $\mathbf{H}$ & \multicolumn{5}{|c|}{$\mathbf{I}$} \\
\hline & & & + & + & + & + & + & + & - & 1 & 2 & 3 & 4 & 5 \\
\hline \multirow{8}{*}{$\begin{array}{l}\text { Product/ service } \\
\text { demand }\end{array}$} & Product safety & & 0 & & $\Delta$ & & & $\Delta$ & & & & & & (0/ם \\
\hline & Compliance of product & & o & & & & & & & & & & & ()/口 \\
\hline & $\begin{array}{l}\text { Regulated operation in the } \\
\text { industry }\end{array}$ & & - & o & & - & - & o & $\Delta$ & & & & & (0)/ \\
\hline & $\begin{array}{l}\text { Focus on the welfare of } \\
\text { employees }\end{array}$ & & - & o & 0 & & & & $\Delta$ & & & & $\square$ & (0) \\
\hline & Industrial influence & & & - & ○ & - & o & & $\Delta$ & & & $\square$ & & () \\
\hline & Impact on ecology & & - & & ○ & - & o & & $\Delta$ & & & $\square$ & & (0) \\
\hline & Impact on social relation & & o & 0 & & o & o & & $\Delta$ & & & $\square$ & & ( ) \\
\hline & $\begin{array}{l}\text { Industry on other industries } \\
\text { in the region }\end{array}$ & & & - & & o & ○ & 0 & $\Delta$ & & & $\square$ & & (2) \\
\hline \multirow{8}{*}{ Process demand } & Price & & - & & $\Delta$ & & & - & & & & & & ○/口 \\
\hline & Excellent after-sale service & & & & ○ & & - & & & & & & $\square$ & (0) \\
\hline & Corresponding speed & & o & & & & & & & & & & & (0/口 \\
\hline & Environmental protection & & ० & & & & & & & & & & & ○/ロ \\
\hline & Production safety & & o & & - & & & & $\Delta$ & & & & $\square$ & (0) \\
\hline & Costs & & o & & & & & & & & & & & (0/ם \\
\hline & $\begin{array}{l}\text { Health and safety of } \\
\text { employees and society }\end{array}$ & & - & - & o & & - & $\circ$ & $\Delta$ & & & $\square$ & & (2) \\
\hline & Harmonious partnership & & & - & 0 & & - & & & & & $\square$ & & (0) \\
\hline
\end{tabular}

Notes: A: Importance

B: Comprehensive quality management system

C: Perfect logic structure

D: Focus more on the result and highlight the result of man and society

E: Able to be applied in the assessment of the industrial development quality in different industries

F: Adapted to the features of different regions

G: Able to help the region managers to find out problems

$\mathrm{H}$ : Uncertainty in the assessment

I: Applicability assessment

\section{Use CAF to assess the development quality of regional industry}

Due to the particularity of development quality assessment in different regions and industries, CAF shall be adjusted according to the actual conditions of the region when used to assess the development quality of regional industry. 


\subsection{Expansion of CAF 9-factor concept}

CAF is traditionally used in public organization field, and each factor is conventionally defined according to the internal and external conditions of the organization. As this article expands the application field of CAF, it is necessary to have a second adjustment of CAF's traditional definition (As shown in Table 3).

Table 3. Expansion of 9-factor concept.

\begin{tabular}{|c|c|}
\hline 9-factor & Definition of expansion \\
\hline Leadership & Overall leadership of regional industry \\
\hline Strategy and planning & $\begin{array}{l}\text { Overall ability to formulate strategies and the plans to realize them } \\
\text { for regional industry }\end{array}$ \\
\hline Human resources & Ability of regional industry to manage the human resources \\
\hline Partnership and resources & $\begin{array}{l}\text { Ability of regional industry to use the external relevant parties, } \\
\text { resources, technologies, equipment and other resources. }\end{array}$ \\
\hline $\begin{array}{l}\text { Process and innovation } \\
\text { management }\end{array}$ & $\begin{array}{l}\text { Identification, management, improvement and other key processes } \\
\text { for the implementation of regional industry strategies and plans. }\end{array}$ \\
\hline $\begin{array}{l}\text { Citizen/client-oriented } \\
\text { result }\end{array}$ & $\begin{array}{l}\text { Results from providing the citizens with product/service by the } \\
\text { regional industry }\end{array}$ \\
\hline Employee-oriented result & $\begin{array}{l}\text { Results from the overall competitiveness, activities, working } \\
\text { satisfaction, performance and other aspects of the employees in the } \\
\text { regional industry. }\end{array}$ \\
\hline Social result & $\begin{array}{l}\text { Contributions the regional industry has made to the environment of } \\
\text { social development and in facilitating the sustained development of } \\
\text { regional industry. }\end{array}$ \\
\hline Result of key performance & Result and trend of key indexes for regional manager \\
\hline
\end{tabular}

The regional manager refers to the one who acts as a policy maker, constructor of industrial development environment and coordinator of interests for each party. Generally, the generally or industry association will play a relevant role. The enterprise citizen refers to an enterprise individual in the region as a basic unit in this research.

\subsection{Framework of assessment index system}

Due to the regional and industrial features, the variation of management level and other reasons, the efficient assessment of development quality of regional industry shall be improved and form a new index system according to the actual conditions.

In the large framework of CAF model, this article has set a quantitative index easy for regional measurement in order for convenient measurement (As shown in Table 4).

Table 4. Index system.

\begin{tabular}{lllll}
\hline $\begin{array}{l}\text { Serial } \\
\text { No. }\end{array}$ & Latent variable & $\begin{array}{l}\text { Serial } \\
\text { No. }\end{array}$ & Observed variable & $\begin{array}{l}\text { Grading reference } \\
\text { panel }\end{array}$ \\
\hline \multirow{3}{*}{ L } & \multirow{3}{*}{ Leadership } & L1 & Culture construction and management & Positive panel \\
& & L2 & Management of working system & Positive panel \\
& & L3 & Performance management & Positive panel \\
& L4 & Risk management & Positive panel \\
SP & \multirow{2}{*}{ Strategy and plan } & SP1 & Strategy formulation & Positive panel \\
& & SP2 & Strategy deployment & Positive panel \\
HR & Human resources & HR1 & Assessment of human resources & Positive panel \\
& & HR2 & Study and development of employees & Positive panel \\
\hline
\end{tabular}




\begin{tabular}{|c|c|c|c|c|}
\hline $\begin{array}{l}\text { Serial } \\
\text { No. }\end{array}$ & Latent variable & $\begin{array}{l}\text { Serial } \\
\text { No. }\end{array}$ & Observed variable & $\begin{array}{l}\text { Grading reference } \\
\text { panel }\end{array}$ \\
\hline \multirow{4}{*}{ PR } & \multirow{4}{*}{$\begin{array}{l}\text { Cooperative companion } \\
\text { and resources }\end{array}$} & HR3 & Management of rationalized advice & Positive panel \\
\hline & & PR1 & Management of supplier & Positive panel \\
\hline & & PR2 & Customer management & Positive panel \\
\hline & & PR3 & Internal management & Positive panel \\
\hline \multirow{2}{*}{ PMI } & \multirow{2}{*}{$\begin{array}{l}\text { Process management } \\
\text { and innovation }\end{array}$} & PMI1 & Process management & Positive panel \\
\hline & & PMI2 & Innovation performance & Positive panel \\
\hline \multirow{2}{*}{ CR } & \multirow{2}{*}{$\begin{array}{l}\text { Citizen/customer- } \\
\text { oriented result }\end{array}$} & CR1 & Management of customer satisfaction & Result panel \\
\hline & & CR2 & Management of customer complaints & Result panel \\
\hline \multirow{2}{*}{ ER } & \multirow{2}{*}{$\begin{array}{l}\text { Result from employee's } \\
\text { perspective }\end{array}$} & ER1 & Management of employee satisfaction & Result panel \\
\hline & & ER2 & Management of employee complaints & Result panel \\
\hline \multirow[b]{2}{*}{ SR } & \multirow{2}{*}{$\begin{array}{l}\text { Society } \\
\text { Result }\end{array}$} & SR1 & Social benefits & Result panel \\
\hline & & SR2 & $\begin{array}{l}\text { Support for public interests and } \\
\text { public services }\end{array}$ & Result panel \\
\hline \multirow{2}{*}{ KR } & \multirow{2}{*}{$\begin{array}{l}\text { Result of key } \\
\text { performance }\end{array}$} & KR1 & External result & Result panel \\
\hline & & KR2 & Internal result & Result panel \\
\hline
\end{tabular}

\subsection{Grading mode}

CAF grading system can grade each secondary index based on PDCA cycle, and use the positive and result panel for grading according to the different natures and functions of each index. The positive and result panel may provide a quantitative grading mode and use the enterprise selfassessment mode.

This article has improved the problems of inaccurate grading, subjective factors and maneuverability that possibly exist in the grading system. In the investigation, we used the questionnaires to measure the management maturity of each enterprise in the regional industry, and adopted 5-grade system quantitative maturity index to finally get the situation of regional quality development. Grading reference panel is as shown in Table 5 and Table 6:

Table 5. Grading panel for positive factor.

\begin{tabular}{lll}
\hline Phase & Panel for positive factor & Grade \\
\hline \multirow{3}{*}{ Plan } & We are not active in this field, or have no information or know little about it. & 0 \\
Implementation & We plan to do this. & 1 \\
Inspection & We are implementing/doing this. & 2 \\
Improvement & We inspect/review whether we did the right thing in a right way. & 3 \\
PDCA & We made adjustment when necessary according to the inspection/review. & 4 \\
& We regularly plan, implement, inspect and adjust all that we did and learn & 5 \\
\hline & from others. We are in a constant improvement cycle. & 5 \\
\hline
\end{tabular}

Table 6. Grading panel for result factor

\begin{tabular}{ll}
\hline Panel for result factor & Grade \\
\hline No measurement or available information & 0 \\
The result is measured and presents a declining trend, not satisfying the relevant indexes. & 1 \\
The result shows a horizontal trend, satisfying some of the relevant indexes. & 2 \\
The result shows a rising trend, satisfying most of the relevant indexes. & 3 \\
The result shows a material progress, satisfying all of the relevant indexes. & 4 \\
Realize an excellent and consistent result that satisfies all of the relevant indexes, and & 5 \\
positively compare all the formulated key results to relevant organizations. & 5 \\
\hline
\end{tabular}




\section{Conclusion}

The development quality of regional industry has a large degree of uncertainty due to local features, measurement scope and other reasons. Based on CAF, this article discusses the feasibility of $\mathrm{CAF}$ as a measurement tool for the development quality of regional industry, and adjusts the index system according to regional features and actual operation. It is a preliminary attempt to measure the development quality of regional industry, which helps create new methods to measure the development quality of regional industry and assists the regional manager to grasp the overall situation of industrial development quality in the region.

Through theoretical verification, CAF has satisfied the requirement of assessing the regional industry development in objective applicability, compatibility of assessed content, logical completeness and completeness of assessment index. Improved to be a more complete and scientific index system, it is also able to measure the development quality of regional industry in a more reasonable way.

\section{References}

1. Cheng, H. Research on the basic theory of macro quality management--An analysis perspective based on quality security [J]. Journal of Wuhan University (Philosophy and Social Sciences Edition), 2010, 1: 129-134.

2. Cheng, H., Li, Q.Q. Research on the system of overall regional quality index model and its assessment [J]. Management World, 2009, (1).

3. Claes Fornel, Liu, J.L. Customer Satisfaction and ACSI [M]. Tianjin: Tianjin University Press, 2006.

4. Liu, Y.C. Construction of index system for development quality assessment [J]. Lanzhou Academic Journal, 2009, 189(6): 78-82.

5. Hu, S.H., Li, Z.H., Mou, R.Y., et al. Industrial "three-power" assessment model and its application [J]. China Software Science, 2012, (5): 40-47.

6. Liu, W.L., Chen, Y. Research on the industrial quality ladder of Chinese manufacture industry [J]. Chinese Industrial Economy, 2012, (296)11: 58-70.

7. An, L.N., Research on the Index System of Cultural Industry Assessment--Empirical Research Based on Hebei Province [D]. Hebei University of Business \& Economics, 2014, 3: 16-18.

8. Liu, X.T., Zong, X.D. Assessment of common assessment framework in the public departments of EU countries [J]. Journal of National Administrative College, 2005, (6): 77-80.

9. Wang, M.C., Liu, X.T. Common performance assessment framework of European public departments and its reference meaning [J]. Reference of Public Administrative Education, 2005, (3).

10. Ani MATEI, Elis-Bianca BĂLĂCEANU. Performance through the Common Assessment Framework: A critical review for Romania [J]. Procedia - Social and Behavioral Sciences, 2014, (143): 862-866. 